\title{
WORKSHOP PENGEMBANGAN SOFT-SKILLS BAGI SISWA VOKASI PERHOTELAN DI TANGERANG, INDONESIA.
}

\author{
Septi Fahmi Choirisa', Anton Harianto ${ }^{2}$ \\ ${ }^{1}$ Universitas Multimedia Nusantara \\ ${ }^{2}$ Universitas Multimedia Nusantara \\ septi.choirisa@umn.ac.id, anton.harianto@umn.ac.id
}

\begin{abstract}
Abstrak
Pengembangan diri berguna untuk siswa vokasi melengkapi keterampilan diri dalam berkarir dimasa mendatang. Sekolah vokasi membekali siswa dalam keterampilan teknis yang dapat diaplikasikan didunia kerja. Namun, keterampilan soft-skills menjadi penentu motivasi dan perkembangan karir profesionalitas. Kemampuan siswa dalam berkomunikasi, berkerjasama, kreatif, dapat memecahkan masalah serta kepemimpinan menjadi hal yang dibutuhkan industri. Namun, Pandemi Covid-19 telah membatasi siswa vokasi untuk melatih soft-skills dan hard-skills. Dengan keterbatasan ini, maka ada beberapa keterampilan yang tidak bisa diasah secara maksimal. Disisi lain, Industri Pariwisata membutuhkan individu dengan kualitas yang mumpuni. Keadaan kontras ini membuat para siswa harus bersaing lebih ketat dalam mempersiapkan diri. Terbatasnya interaksi dan kebutuhan kualitas yang tetap tinggi dapat dipecahkan melalui pelatihan yang diselenggarakan oleh Universitas Multimedia Nusantara untuk mendukung pengembangan diri siswa vokasi Indonesia. Pelatihan ini bekerjasama dengan SMKN 7 Kabupaten Tangerang secara daring melalui Aplikasi Zoom, sehingga dapat berjalan dengan efektif dimasa Pandemi Covid-19. Materi dan modul yang disiapkan oleh tim pengusul mampu memberikan pemahaman secara komperhensif oleh siswa/siswi SMKN 7. Kegiatan ini memenuhi kebutuhan siswa/siswi vokasi dalam pengembangan potensi diri baik dalam segi akademis maupun praktis.
\end{abstract}

Kata Kunci : Sekolah Vokasi, Soft-skill, Pandemi Covid-19.

\section{PENDAHULUAN}

Indonesia merupakan salah satu negara yang terinfeksi pandemi Covid-19. Virus Covid 2019 (COVID-19) adalah penyakit menular yang disebabkan oleh sindrom pernapasan akut corona virus 2 (SARS-CoV-2). Efek dari adanya virus ini memiliki peran yang sangat besar akan berubahnya kegiatan bermasyarakat. Kondisi ini memiliki efek domino kepada beberapa sektor, termasuk sektor Pendidikan. Dampak dari virus ini merubah proses belajar mengajar dari pertemuan tatap muka menjadi pertemuan secara daring. Berdasarkan Riset Nielsen yang bertajuk "Race Against the Virus, Indonesian Consumer Response towards COVID-19" mengungkapkan bahwa sebanyak $50 \%$ masyarakat Indonesia mulai mengurangi aktivitas di luar rumah, dan $30 \%$ di antaranya mengatakan bahwa mereka berencana untuk lebih sering berbelanja online. Begitu juga kegiatan proses belajar mengajar dilaksanakan dari rumah bahkan bekerja pun dilakukan dari rumah dengan tujuan agar bisa mengurangi penularan Covid-19. (Siahaan, 2019). 
Dengan adanya Pandemi Covid-19, sistem Pendidikan di Indonesia mengalami perubahan. Disrupsi teknologi yang terjadi yakni pembelajaran tatap muka yang dilaksanakan 100 persen di sekolah, secara tibatiba mengalami perubahan yang sangat drastis. Tidak bisa dipungkiri di atas 50 persen pelajar dan mahasiswa berasal dari masyarakat berpenghasilan rendah dan menengah. (Siahaan, 2019). Di masa transisi Covid-19 saat ini, dibutuhkan inovasi model pembelajaran vokasi yang efektif digunakan. Pendidikan vokasi di Indonesia menjadi prioritas pemerintah dalam upaya meningkatkan sumber daya manusia agar memiliki keterampilan dan daya saing. Pendidikan Vokasi secara umum dapat didefinisikan sebagai bentuk pendidikan yang memberikan pengetahuan dan keterampilan profesional secara khusus (Kotsikis, 2007). Secara konsep, pendidikan vokasi merupakan kelas yang dibuat untuk membangun siswa dalam menyiapkan diri untuk masuk ke dunia kerja (Ireland, 2008). Menurut Hoachlander dan Kaufman (1992) pakar pendidikan dari NCES (National Center for Education Statistics) USA: vocational education is intended to help prepare students for work, both inside and outside the home, many educators believe it has a broader mission: to provide a concrete, understandable context for learning and applying academic skills and concepts.

Disrupsi yang terjadi di dunia Pendidikan ini berimbas kepada sekolah kejuruan yang ada di Indonesia. Khususnya, di program studi perhotelan yang membutuhkan keterampilan khusus dalam hardskill dan softskill, siswa tidak mendapatkan keterampilan yang seharusnya menjadi bekal dimasa mendatang secara cukup. Pembekalan khusus yang disiapkan sekolah kejuruan menjadi terbatas dalam kondisi pandemi namun kebutuhan industri akan kualitas sumber daya manusia tetap tinggi. Keterampilan pengembangan diri seperti personal branding, bahasa dan pengenalan karakter dan budaya lain terhalangi dengan sistem pembelajaran online.

Perubahan tahapan kehidupan untuk siswa vokasi menjadi seorang yang profesional bukanlah hal yang mudah. Siswa kerap kali dihadapkan dengan tantangan ketika mereka mamasuki kehidupan profesionalitas. Mereka diharapkan mampu menyesuaikan diri secara cepat dengan lingkungan baru dengan menerapkan konsep pengetahuan yang mereka miliki (Anjum, 2020). Beberapa studi menjelaskan bahwa ada interaksi signifikan antara lingkungan tempat bekerja dengan identifikasi keahlian siswa. Faktor yang paling signifikan adalah faktor adaptasi lingkungan kerja baru yang sering kali berkenaan dengan kesiapan siswa secara mandiri (Peasland, 2019). Kesiapan siswa dapat berkenaan dengan softskill atau pengembangan diri. Ada cara berbeda mendefinisikan dan mengelompokan softskill dalam keterampilan hidup (WHO, 1993), keterampilan abad ke-21 (Moore and Morton 2017), keterampilan transversal, kompetensi umum sama seperti kunci keterampilan sukses yang berfungsi dimasyarakat dan pembelajaran kekal (OECD 2003, 2012).

Menurut Sin dan Neave (2016), sekolah atau universitas berperan penting pada menyiapkan siswa/siswi mereka untuk kebutuhan perusahaan atau pasar dengan mengembangkan keterampilan "siap kerja". Namun, keterampilan ini tidak dibekali oleh keterampilan pengembangan diri yang sama pentingnya dengan keahlian siswa/siswi. Berdasarkan penelitian yang dijalankan oleh Haselberger dan tim (2012), menyatakan bahwa keterampilan softskill merepresentasikan kombinasi dinamis antara kognitif dan keterampilan meta-kognitif, interpersonal, 
intelektual dan keterampilan praktis. Keterampilan soft-skills membantu siswa/siswi dalam berdaptasi dan memiliki sikap yang positif sehingga mereka dapat bekerja secara efektif dengan tantangan sebagai profesional. Keterampilan ini selaras dengan sehubungan dengan hubungan interpersonal dan kualitas sosial serta kompetensi dimanapun sektor industrinya (Hurell, 2016; Deloitte, Access Economics, 2017). Soft-skills ini termasuk komunikasi, bekerjasama dengan tim, menyelesaikan masalah, pemikiran kritikal dan inovatif, kreatifitas, kepercayaan diri, memahami etika, kapasitas pembelajaran yang kekal, kemampuan mengatasi ketidakpastian dan kesediaan menerima tanggungjawab (Harvey, 2000; Andrews dan Higson 2008, Kalfa dan Taksa, 2015; Clarke, 2017, Moore and Morton, 2017).

Berdasarkan artikel yang dirujuk oleh Media Indonesia (2020), lulusan Pendidikan vokasi secara umum memiliki kendala dalam menghadapai tekanan dalam dunia kerja. Mereka dianggap minim dalam softskill seperti kurang dapat berkerja sama dalam tim, kurangnya komunikasi baik secara lisan maupun tulisan serta dinilai kurang inisiatif. Ada beberapa keluhan dari industri yang disorot khususnya lulusan vokasi yakni mudah bosan dan menunggu perintah atasan (Winahyu, 2020). Kemampuan soft-skill dari sekolah vokasi harus diutamakan agar lulusan yang dihasilkan memiliki standar yang dibutuhkan oleh industry. Tujuan utamanya yakni memiliki daya saing dan produktifitas yang tinggi melalui sumber daya manusia yang unggul.

Kemampuan softskill yang dibutuhkan oleh industri akan lulusan sekolah vokasi yakni kemampuan komunikasi, kepemimpinan, manajerial, dapat bekerja baik secara individu maupun tim, kemampuan menerima perbedaan, berpikir kritis serta berpikir kreatif (Sasongko, 2020).
Dengan adanya kondisi ini, maka tim dari Program Studi Perhotelan Universitas Multimedia Nusantara dapat memberikan fasilitas pelatihan untuk pengembangan diri untuk sekolah menengah kejuruan di Tangerang, Indonesia. Kegiatan ini diharapkan mampu membantu calon insan perhotelan dalam mempersiapkan bekal keterampilan khusus agar mampu bersiang dimasa mendatang. Pengabdian Kepada Masyarakat (PKM) ini akan terfokus pada pembekalan pengembangan diri bagi siswa perhotelan SMKN Kabupaten Tangerang, Indonesia. Kegiatan ini mengingatkan siswa vokasi tentang pentingnya pengembangan soft skills untuk memahami ekspektasi dunia kerja (Succi and Canovi, 2019). Dengan urgensi masalah tersebut, kegiatan ini dapat dirumuskan sebagai berikut: 1) Bagaimana siswa perhotelan mempersiapkan pengembangan diri di situasi pandemi Covid-19? 2) Apa hambatan dan kesempatan yang dapat ditangani oleh siswa perhotelan pada situasi pandemi Covid-19?. Adapun tujuan dari program ini yakni : 1) Memberikan persiapan secara mental dan pengembangan diri yang dibutuhkan siswa perhotelan pada situasi pandemi Covid-19, 2) Memberikan solusi akan hambatan dan gambaran kesempatan yang akan dihadapi oleh siswa perhotelan pada pandemi Covid-19.

\section{METODE}

Kegiatan pengabdian kepada masyarakat dilaksanakan dalam virtual workshop dengan judul "Workshop Personal Development for Hospitality Students". Kegiatan ini diselenggarakan pada tanggal 23 April 2021 di SMKN 7 Kabupaten Tangerang, Indonesia. Peserta yang daftar adalah 153 siswa dengan peserta yang hadir pada saat pelaksanaan yakni berjumlah 92 siswa vokasi SMKN 7 Kabupaten Tangerang. Acara ini dibantu oleh mahasiswa perhotelan yang berjumlah sekitar 10 orang untuk mengatur 
jalannya acara, absensi, dokumentasi, pengoperasian teknis online dan pemberian sertifikat. Acara ini diselenggarakan secara daring melalui aplikasi Zoom Fakultas Bisnis Universitas Multimedia Nusantara dengan Program Studi Hotel Operations yang menjadi host kegiatan ini. Instruktur pelatihan ini diprakarsai oleh tim dosen dan mahasiswa yang terdiri dari 2 (dua) orang dosen dan 6 (enam) orang mahasiswa. Metode pembekalan dan pelatihan yang digunakan yakni; paparan, diskusi dan pemberian modul yang dapat mereka dapatkan guna menjadi panduan pengembangan diri di manajemen pelayanan. Pelaksaan kegiatan pada pembelajaran daring ini didesain layaknya kelas seminar guna menghasilkan materi dan diskusi yang efektif. Berikut topik yang diberikan sebagai materi pelatihan pengembangan diri, sofskill untuk siswa vokasi :

Tabel 1. Susunan Materi Pelatihan

\begin{tabular}{cl}
\hline No & \multicolumn{1}{c}{ Materi } \\
1 & Definisi Self-Awareness \\
2 & 6 Ways to improve Self-Awareness \\
3 & Definsi Personal Development \\
4 & 3 Basic Characteristic to shape \\
& personal branding \\
5 & Discover and Develop the Talents \\
6 & 3 Simple ways to discover the talents \\
\hline
\end{tabular}

Setelah acara pelatihan daring berakhir. Tim pengusul dari Universitas Multimedia Nusantara memberikan modul dan poster secara langsung kepada pihak SMKN 7 Kabupaten Tangerang, yang diharapkan mampu memperkaya ilmu dari materi yang diberikan. Materi modul dan poster didistribusikan oleh guru kepada siswa/siswi yang hadir pada kelas online sesuai dengan absensi yang berjalan pada saat kegiatan pengabdian kepada masyarakat.

\section{HASIL DAN PEMBAHASAN}

Kegiatan yang dilaksanakan secara daring ini dikelompokan dalam beberapa poin yang diterangkan secara berkesinambungan. Pembahasan mengenai pengembangan keterampilan diri dilakukan secara paparan dan diskusi secara efektif dalam rangka penyerapan materi dalam dua arah. Menurut Haselberger (2012) ada beberapa kategori pengembangan diri melalui soft-skills seperti: personal, social dan methodological. Kategori personal mencangkup memiliki komitmen bekerja, memiliki etika profesional, kemampuan toleransi akan stress, kreatifitas, keterampilan belajar, keterampilan dalam menyeimbangkan kehidupan pribadi dan pekerjaan serta keterampilan memahami kemampuan diri. Kategori selanjutnya yakni sosial, dimana individu memiliki kemampuan berkomunikasi, mempunyai kemampuan manajemen konflik dan negosiasi, keterampilan mengembangan jaringan, keterampilan berdaptasi dalam budaya, keterampilan kepemimpinan dan dapat berkerja bersama tim. Kategori terakhir yakni memiliki keterampilan untuk merubah keahlian, menganalisis, terus-menerus berkembang, berorientasi pada pelanggan, kemampuan untuk menentukan keputusan, kemampuan manajemen dan beriorientasi pada hasil.

Berdasarkan rujukan kategori tersebut, kegiatan ini merangkup beberapa poin yang tertera pada penelitian yang sudah dijalankan dan diterapkan dalam acara pengabdian kepada masyarakat ini. Pembahasan pertama yakni mengenai identifikasi pengenalan diri atau selfawareness. Self-awareness dikonsiderasikan secara general sebagai inti pekerjaan sosial yang efektif baik secara pendidikan dan praktik secara professional (Blakemore and Agllias, 2019). Hal ini berkaitan dengan dasar penerimaan diri akan pengenalan atau pengenalan keahlian diri yang sering kali tidak terucap seperti pemikiran, perasaan, motivasi 
dan sikap (Richards, 2010). Dapat diartikan juga sebagai pemahaman orang lain atas diri seseorang (Heydt dan Sherman, 2005), pengujian kritikal atas kepribadian seseorang termasuk profesionalitas yang dipengaruhi dominan oleh ideologi seseorang (Bransford, 2011).

Pada tahap ini siswa vokasi diberikan pemahaman definisi pengenalan diri dalam bermacam perspektif ahli. Tahap kedua yakni memberikan enam cara meningkatkan pengenalan diri, seperti 1) Meminta saran dari oranglain, 2) Memahami kekurangan dan kelebihan diri masing-masing, 3) Refleksi diri, 4) Memahami pembicaraan diri, 5) Belajar untuk mengatakan tidak pada hal yang tidak berkenaan dengan target pribadi, 6) Meyakinkan keputusan yang diraih. Setelah memahami pengenalan diri atau potensi dari masing-masing, siswa vokasi diberikan perkenalan definisi tentang pentingnya personal branding dari pandangan beberapa ahli. Personal Branding telah menjadi fitur yang menonjol dari pasar tenaga kerja, baik dalam kondisi offline atau tatap muka maupun melalui platform offline (Vallas dan Christin, 2017). Karakteristik yang dibutuhkan dalam manajemen personal branding, yakni; 1) Otentisitas dari masing-masing siswa vokasi yang memiliki nilai spesifik yang berbeda, keunikan dari pribadi sebagai individu yang berkualitas., 2) Relevansi, ialah pada saat karakter siswa vokasi dapat memenuhi kebutuhan masyarakat., 3) Konsistensi, siswa vokasi diharpakan mampu membuktikan keunikan atau brand yang dibangun secara konsisten dalam setiap kegiatan yang dilakukan, bentuknya bisa dalam tampilan berpenampilan ataupun dalam bentuk apapun yang mampu diingat mudah oleh masyarakat. Setelah mengenal karakteristik yang diperlukan dalam personal branding, siswa vokasi diberikan pengetahuan mengenai definisi pengenalan dan pengembangan bakat. Strategi personal branding yang diberikan kepada siswa/siswi SMK Vokasi penting untuk mengelola pribadi yang kompetitif. Pada saat yang sama, diversifikasi angka kebutuhan kerja menentukan kekhususan ahli atau bakat yang akan mempengaruhi personal branding. Mengingat branding yang kuat dan jelas menjadi kunci dalam penjabaran, implentasi dan menjaga branding seseorang. Salah satu masalah yang disebabkan oleh evolusi teknologi dan kemajuan pengetahuan terhubungan dengan ketidakcocokan antara keterampilan yang dimiliki seorang pekerja dan tuntutan nyata ekonomi (Berger dan Frey, 2016). Kesenjangan itu bisa dijembatani dengan cara yang berbeda, misalnya, melalui pelatihan regular karyawan atau daya tarik tenaga ahli uang dibutuhkan dari luar negeri. Karyawan yang berbakat adalah salah satu kelompok tenaga kerja yang paling diinginkan karena produktifitas mereka yang lebih tinggi.

Kemampuan mereka memungkinkan untuk mencapai hasil ekonomi yang lebih tinggi, yang berkontribusi terhadap pembangunan daerah secara keseluruhan (O'Boyle dan Aguinis, 2012; Khilji et al., 2015). Konsep kontemporer tentang bakat manajemen berpusat pada manusia dan pendekatan manajemen bergantung pada siapa orang yang memenuhi syarat sebagai orang yang berbakat (Crane dan Hartwell, 2018). Bakat yang tersembunyi termasuk kemampuan untuk mendeteksi dan mengingat tantangan, menemukan solusi kreatif, memahami orang lain dan dapat menghadapi perubahan lingkungan (Frankenhuis, et al., 2020). Dalam tahap ini, siswa akan mengenal bahwa bakat adalah keterampilan yang secara naluriah didapatkan oleh individu. Tahap terakhir yakni pada saat siswa vokasi diberikan materi tentang bagaimana cara menemukan bakat pribadi, yaitu: 1) Membuka pikiran, 2) Mencoba sesuatu yang baru, 3) Melakukan sesuatu yang paling dikuasai. 
Kegiatan ini menjawab pertanyaan urgensi masalah siswa vokasi tentang memberikan materi personal development pada saat pandemi Covid-19. Kegiatan ini juga membahas dan berdiskusi tentang hambatan dan kesempatan yang dapat ditangani oleh siswa perhotelan pada situasi pandemi Covid19. Kegiatan ini telah mencapai tujuannya yakni memberikan persiapan secara mental dan pengembangan diri yang dibutuhkan siswa perhotelan pada situasi pandemi. Dengan pembahasan dan diskusi secara dua arah, kegiatan ini dapat memberikan solusi akan hambatan dan gambaran kesempatan yang akan dihadapi oleh siswa perhotelan pada pandemi Covid-19.

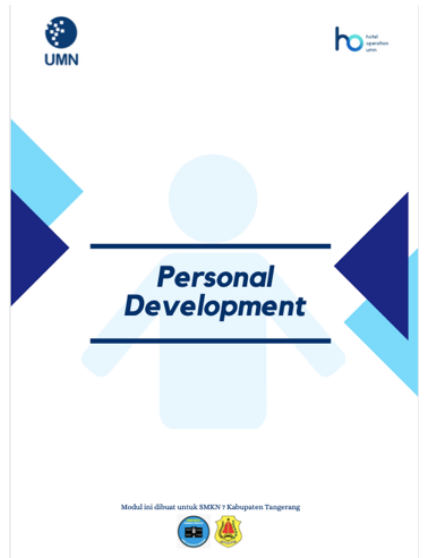

Gambar 1. Tampilan depan Modul Personal Development

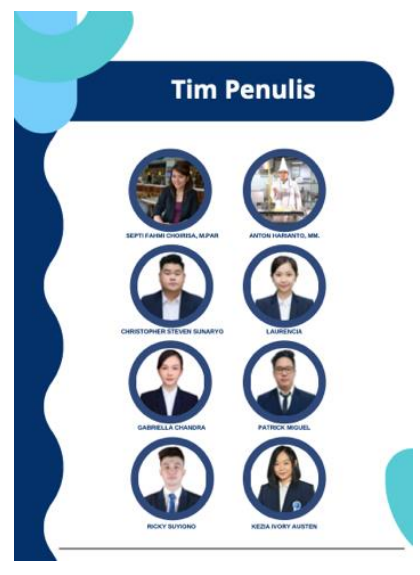

Gambar 2. Tim Penyusun Modul Personal Development

Gambar 3. Pelaksanaan Kegiatan diadakan secara online melalui aplikasi Zoom
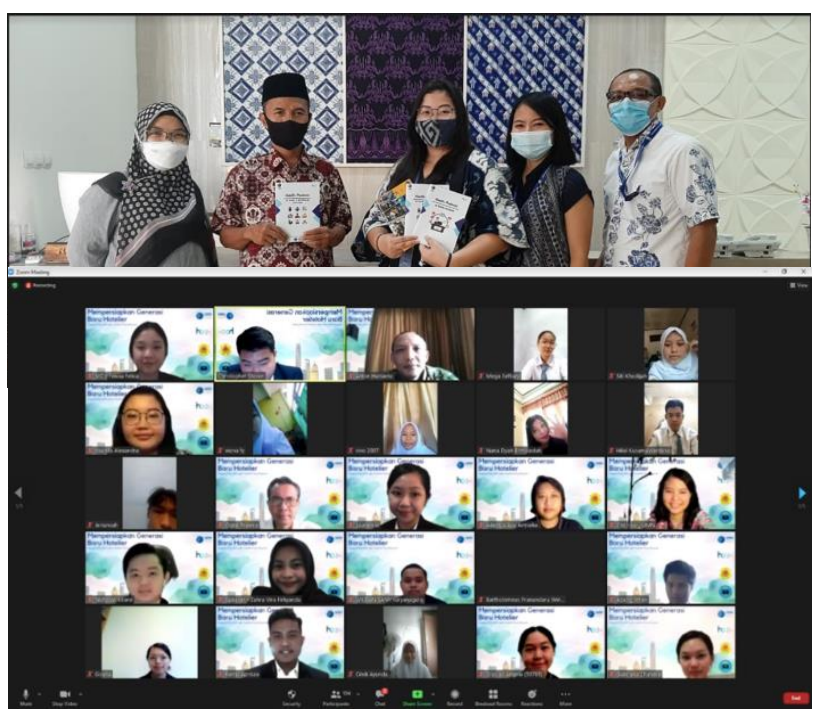

Gambar 4. Pemberian Modul untuk SMKN 7 Kabupaten Tangerang "Personal Development"

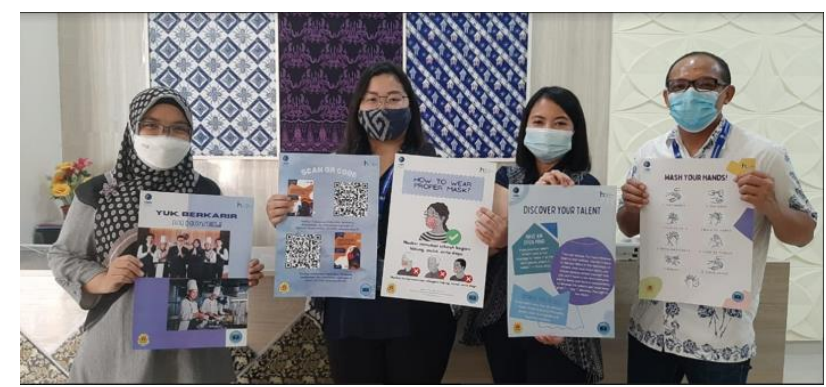

Gambar 5. Pemberian Poster untuk SMKN 7 Kabupaten Tangerang "Personal Development"

\section{KESIMPULAN}

Kegiatan pengabdian kepada masyarakat ini berdampak signifikan pada pengetahuan siswa vokasi pengembangan diri. 
Siswa dapat mengukur keterampilan diri yang akan disiapkan kedepan untuk memenuhi kebutuhan Industri Pariwisata. Siswa/siswi SMKN Kab. 7 Tangerang merasa lebih paham akan pengenalan diri dan pengembangan potensi diri yang mampu meningkatkan kepercayaan diri atas keterampilan individu. Setelah mengikuti kegiatan ini, siswa/siswi diharapkan mengisi modul yang sudah diberikan oleh tim dari program kegiatan ini sehingga mereka dapat mengetahui kekuatan, kelemahan dan talenta yang dimiliki. Selain itu, melalui modul tersebut, siswa/siswi diberikan kesempatan menuliskan target kedepan dalam berkarir dan berkarya dimasa mendatang.

Keterampilan yang dipersiapkan di sekolah lebih banyak berkenaan dengan hardskill sedangkan kebutuhan siswa/siswi akan soft-skill juga tidak kalah penting. Dengan diadakannya kegiatan ini, siswa/siswi vokasi menjadi lebih lengkap pengetahuannya mengenai kedua aspek yang penting untuk melengkapi kompetensi dunia kerja. Para siswa/siswi sekolah vokasi diharapkan dapat membangun soft-skill yang kuat dalam rangka persiapan menuju dunia kerja di Industri Pariwisata yang dapat berpotensi meningkatkan kinerja dan kepercayaan diri dalam berkarir khususnya disektor pariwisata, baik hotel, travel maupun berwirausaha.

Kegiatan ini akan lebih berdampak jika dilaksanakan melalui kelas tatap muka agar siswa/siswi dapat melakukan praktikum. Kegiatan praktikum guna mengasah soft-skills dapat dilaksanakan dalam kelas kemampuan bahasa asing, kelas kepribadian dan kelas public speaking yang dapat meningkatkan rasa kepercayaan diri siswa/siswi SMKN 7 Kabupaten Tangerang. Kelas tatap muka juga dapat memfasilitasi kelas mentoring individu agar siswa/siswi dapat leluasa untuk bertanya dan mentor dapat memberikan saran secara pribadi untuk memenuhi karakteristik siswa yang berbeda-beda. Kegiatan yang dilakukan secara kontinuitas akan membantu para siswa/siswi siap dalam menghadapai tantangan dan beradaptasi pada lingkungan kerja baru serta menjadi pribadi yang berkualitas.

\section{UCAPAN TERIMAKASIH}

Kegiatan Pengabdian Kepada Masyarakat ini didanai penuh oleh Universitas Multimedia Nusantara pada tahun 2020.

\section{REFERENSI}

Andrews, J., and Higson, H. 2008. Graduate Employability, Soft Skills Versus Hard Business Knowledge: A European Study. Higher Education in Europe 33 (4): 411422.

Anjum, S. 2020. Impact of internship programs on professional and personal development of business students: a case study from Pakistan. Future Business Journal 6. https://doi.org/10.1186/s43093-019-00073

Berger, T., and C. Frey. 2016. Structural transformation in the OECD: Digitalisation, deindustrialisation and the future of work, ISSN: 1815199X (online). https://doi.org/10.1787/1815199X

Blakemore, T., \& Agllias, K. (2018). Student Reflections on Vulnerability and Selfawareness in a Social Work Skills Course. Australian Social Work, 72(1), 21-

33. doi:10.1080/0312407x.2018.1516793

Bransford, C. L. (2011). Integrating critical consciousness into direct social work practice: A pedagogical view. Social Work Education, 30(8), 932-947. doi:10.1080/02615479.2010.534449

Chiara Succi \& Magali Canovi (2019): Soft skills to enhance graduate employability: comparing students and employers' 
perceptions, Studies in Higher Education, DOI: $10.1080 / 03075079.2019 .1585420$

Clarke, M. 2017. "Rethinking Graduate Employability: the Role of Capital, Individual Attributes and Context." Studies in Higher Education 43 (11): 1923-1937.

Crane, B., and C.J. Hartwell. 2018. Global talent management: A life cycle view of the interaction between human and social capital. Journal of World Business 54 (2): 8292. https://doi.org/10.1016/j. jwb.2018.11.002.

Deloitte Access Economics. 2017. Soft Skills for Business Success. https://www2.deloitte.com/content/dam/D eloitte/au/Documents/Economics/deloitteau-economics-deakin-soft-skills-businesssuccess-170517.pdf.

Deloitte. 2017. Global Human Capital Trends. https://www2.deloitte.com/global/en/page s/human-capital/articles/ introductionhuman-capital-trends.html.

Emma L. Peasland, Dominic C. Henri, Lesley J. Morrell \& Graham W. Scott (2019) The influence of fieldwork design on student perceptions of skills development during field courses, International Journal of Science Education, 41:17, 23692388, DOI: 10.1080/09500693.2019.1679 906

Frankenhuis, W. E., Young, E. S., \& Ellis, B. J. (2020). The Hidden Talents Approach: Theoretical and Methodological Challenges. Trends in Cognitive Sciences. doi:10.1016/j.tics.2020.03.007

Harvey, L. 2000. "New Realities: The Relationship Between Higher Education and Employment." Tertiary Education \& Management 6 (1): 3-17.

Haselberger, D., P. Oberheumer, E. Perez, M. Cinque, and D. Capasso. 2012. Mediating Soft Skills at Higher Education
Institutions, Handbook of ModEs Project, Life Long Learning Programme

Heydt, M. J., \& Sherman, N. E. (2005). Conscious use of self: Tuning the instrument of social work practice with cultural competence. Journal of Baccalaureate Social Work, 10(2), 25-40. doi:10. 18084/1084-7219.10.2.25

Hoachlander E.,Gareth,Kaufman, Phillip. 1992. Vocational education in the United States 1969-1990. USA:National Center For Education Statistics. (http://nces.ed.gov/pubs92/92669.pdf.082019).

Hurrell, S. A. 2016. "Rethinking the Soft Skills Deficit Blame Game: Employers, Skills Withdrawal and the Reporting of Soft Skills Gaps." Human Relations 69 (3): 605-628.

Ireland, A. N. (2008). Definition of vocational education and training. Reseach and Library Services, 64, 21-26.

Kalfa, S., and L. Taksa. 2015. "Cultural Capital in Business Higher Education: Reconsidering the Graduate Attributes Movement and the Focus on Employability." Studies in Higher Education 40 (4): 580-595.

Khilji, S.E., I. Tarique, and R.S. Schuler. 2015. Incorporating the macro view in global talent management. Human Resource Management Review 25: 236-248. https://doi.org/10.1016/j.hrmr.2015.04.00 1 .

Kotsikis, V. (2007). Educational Administration and Policy. Athens: Ellin.

Moore, T., and J. Morton. 2017. "The Myth of Job Readiness? Written Communication, Employability, and the 'Skills Gap' in Higher Education." Studies in Higher Education 42 (3): 1-19

O'Boyle Jr., E., and H. Aguinis. 2012. The best $\&$ the rest: Revisiting the norm of 
normality of individual performance. Personnel Psychology 65: 79-119.

OECD. 2003. Definition and Selection of Competencies: Theoretical and Conceptual Foundations (DeSeCo). Summary of the Final Report Key Competencies for a Successful Life and a Well-functioning Society. Paris: OECD Publishing.

OECD. 2012. Better Skills, Better Jobs, Better Lives: A Strategic Approach to Skills Policies. Paris: OECD Publishing.

Richards, K. C., Campenni, E. C., \& MuseBurke, J. L. (2010). Self-care and wellbeing in mental health professionals: The mediating effects of self-awareness and mindfulness. Journal of Mental Health Counseling, 32(3), 247-264. doi:10.17744/mehc.32.3.0n31v88304423 806

Sasongko, Yakob Arfin Tyas (2020), Atasi Gap Tenaga Kerja, Transformasi Pendidikan Vokasi Penting, Kompas. https://edukasi.kompas.com/read/2020/09 /22/172600071/atasi-gap-tenaga-kerjatransformasi-pendidikan-vokasi-jadi-halpenting

Siahaan, Matdio, 2019, Dampak Pandemi Covid-19 Terhadap Dunia Pendidikan, Jurnal Kajian Ilmiah (JKI) e-ISSN: 2597-
792X, ISSN: 1410-9794 Edisi Khusus No. 1 (Juli 2020), Halaman: $73-80$.

Sin, C., and G. Neave. 2016. "Employability Deconstructed: Perceptions of Bologna Stakeholders." Studies in Higher Education 41 (8): 1-16. Succi, C. 2018. "Are You Ready to Find a Job? Ranking of a List of Soft Skills to Enhance Graduates' Employability." International Journal of Human Resources Management and Development.

Succi, C., \& Canovi, M. (2019): Soft skills to enhance graduate employability: comparing students and employers' perceptions, Studies in Higher Education, DOI: $10.1080 / 03075079.2019 .1585420$

Vallas, S. P., \& Christin, A. (2017). Work and Identity in an Era of Precarious Employment: How Workers Respond to "Personal Branding" Discourse. Work and Occupations, 45(1), 337. doi:10.1177/0730888417735662

WHO. 1993. "Life Skills Education in Schools." Skills for Life 1. Genève

Winahyu, Atikah Ishmah (2020), Lulusan Vokasi Lemah Soft-Skill, Media Indonesia.https://mediaindonesia.com/hu maniora/356675/lulusan-vokasi-lemahsoft-skill. 